are given, and the annual operating costs are compared with those for steam haulage. He proves that when the traffic density is fairly high, railway electrification is economically feasible. A discussion of the various methods of electrification shows that the single-phase system has attractive possibilities. $\mathrm{He}$ concludes that if a transport system were developed $a b$ initio in an advanced industrial country like Great Britain, electric working would be extremely attractive. But where a railway is already in existence, the capital cost of converting to electric haulage is of prime importance, the reason being that the problem at the moment is not so much economic as financial.

\section{Memorial to Prof. T. Eric Peet}

As the result of the appeal issued in 1934, the sum of $£ 1,01015 s .9 d$. has been contributed for the purpose of a memorial to Thomas Eric Peet, who was, at the date of his untimely death, professor of Egyptology in the University of Oxford. This sum, it is announced by Prof. J. P. Droop in a letter in The Times of February 7 , has been paid over to the Council of the University of Liverpool for investment. The income from the endowment thus created will be used for the quinquennial award, on the recommendation of the executive committee of the University of Liverpool Institute of Archæology, of a fellowship, tenable for one year by a graduate of a British university, who proposes a course of study either in "The Ancient Egyptian Language and Egyptology" or "The Pre. history of the Mediterranean Lands and/or the Near East". Unless the dispensation of the executive committee is obtained, four months of the year of tenure must be spent out of England. Awards will be made in the month of June of the year of award, and one half of the value of the fellowship (£150) will be paid on award, the balance being payable on receipt of a satisfactory report on his work from the fellow at the close of the first six months. It is within the competence of the Council to vary the terms of the award, so long as the provisions as to the qualifications of candidates and the subjects of study are observed. The first award will be made in 1941.

\section{Immunity in Protozoal Disease}

Thrs was the title of the presidential address delivered by Lieut.-Colonol H. E. Shortt to the Section of Medical and Veterinary Research of the twenty-third Indian Science Congress, Indore (Jan. 2-8). After a brief survey of the subject of immunity in general in infective diseases, Colonel Shortt proceeded to discuss the mechanisms that may exist for the production of immunity in the protozoal diseases trypanosomiasis, malaria, leishmaniasis and piroplasmosis, and concluded that they are very similar to, if not identical with, those which are operative in immunity against bacterial diseases. In the case of malaria, it might be thought that no immunity develops, for individuals may suffer not only from numerous relapses during the course of an attack, but also may be repeatedly re-infected. In the case of natives dwelling in a malarious district, however, it would appear that the community does acquire a relative immunity after about twelve years exposure to infection. One of the factors limiting immunity in protozoal diseases is the development of strains of the parasite immunologically different and distinct from the original infecting strain, and a relapse or a re-infection may be caused by a strain immunologically different from the original one. Thus, it has been shown with the trypanosomes that a mouse, incompletely cured of its infection twenty times, produced seventeen immunologically different relapse strains. A full and useful biblio. graphy is appended to the address.

\section{Co-ordination of Botanical Research in the British Empire}

THE Report of the third Imperial Botanical Con. ference (see NATURE, 136, 402 ; 1935) held in London on August 28-30, 1935, has recently been issued (Royal Botanic Gardens, Kew, price 1s.). Apart from the various discussions reprinted from NATURE, Sir Arthur Hill, president of the Conference, made an eloquent plea for the furtherance of the scheme for the creation of liaison officers from the Dominions and Colonies, thus ensuring closer co-operation with the National Herbarium at Kew. Since 1883, an assistant for India has been working at the Kew Herbarium, supported by the Government of India. The Government of the Union of South Africa similarly maintains an assistant for Africa at Kow. As in these cases, there are preserved in the Kew Herbarium most of the early collections of Australian and New Zealand plants and many from Canada. Naturally, these historic collections cannot leave the country, and it is highly desirable that young botanists from the Dominions should be given the opportunity of working on these collections, of getting into touch with botanical colleagues, and of acquiring a knowledge of methods of work in large British and Continental herbaria and libraries at present out of their reach. A resolution was therefore passed at the Conference that the authorities be asked to appoint liaison officers and exchange officers from Australia, New Zealand and Canada. It was also resolved that the "exchange both of members of the staff and research students between the Universities and Research Institutions and relevant Departments of the Empire" should be encouraged, and the establishment of a permanent committeo for this purpose be recommended.

\section{Chemical Engineering Congress}

Provisional programmes of the business which will be discussed by the twelve sections of the Chemical Engineering Congress of the World Power Conference in June next have just been published. The Congress will meet at the Central Hall, West. minster, on June 22-27; with it will be associated visits to works and opportunities for social inter. course in the form of receptions and a banquet. During the course of the Congress, the British Chemical Plant Manufacturers' Association will hold its periodical exhibition of British chemical plant at 